\title{
ANALISIS PEMILIHAN KARTU GSM PRABAYAR DI KALANGAN \\ MAHASISWA DENGAN PENDEKATAN RANTAI MARKOV \\ (Studi Kasus pada Mahasiswa Universitas Bunda Mulia, Jurusan \\ Manajemen, Semester 8) \\ Indra dan Lanang Diayudha
}

Email: 1diayudha@bundamulia.ac.id

\section{Penulis}

Indra, adalah alumni Universitas Bunda Mulia Jurusan Manajemen

Lanang Diayudha, adalah pengajar tetap Jurusan Manajemen Universitas Bunda Mulia dengan peminatan mata kuliah manajemen pemasaran

\section{Abstract}

The many variety of GSM card and services enables the customers to change brands easily. This has caused a tighter competition between the brands. In order to face the competition, GSM operators need to understand the customers' perception and judgment on the preference scale toward the atribute of the products and services. GSM card operators also need to understand the brand switching pattern and its competitior position in analysing the market today or in the future. By the analyses, the operator hopes to acquired some description of their position and product situation among the tight competition between 4 operators. The description can then be used as input in determining the marketing strategies for the future. The objects in this research are analyzed using Markov's chain method on brand switching. The analysis on customer's judgments on the product attributes and services is aided by the use of descriptive statistics. The case study is performed on the $8^{\text {th }}$ semester students of Bunda Mulia University, majoring in Management. The population is 105 students. The research method is by using survey and the type of research is descriptive research. The data collecting technique is through the use of questionnaire and literary review. The results shows that the source of reference of the customer's choice which is $3.81 \%$ from the event, $12.38 \%$ from families, 29.52 from commercials, $45.71 \%$ from friends, and $8.57 \%$ from other unspecified sources. The prediction of the market from the five operators in consequential orders are $10.0695,0.6401,0.0295$, $0.1207,0.1402)$, and the prediction of equilibrium moment are $(0.0218,0.5805$, 0.0264, 0.117, 0.2543).The biggest market share is owned by XL which is 64.01\%, and the smallest is by mentari with the share of $2.95 \%$. The biggest sorce of reference for the students in choosing operators is from promotion events with the percentage of $30.81 \%$ and from friends is only $19.88 \%$. Looking at this result it 
can be suggested that operators should increase their services and increase their promotion events in gaining the market share of GSM users.

\section{Key Words}

GSM cards, brand switching, Markov's chain, market share

\section{PENDAHULUAN}

Komunikasi menjadi hal yang penting dalam kehidupan manusia. Melalui komunikasi, setiap individu mampu berinteraksi satu dengan lainnya. Seiring perkembangan teknologi, komunikasi menjadi lebih mudah. Misalnya saja adanya ketersediaan telepon yang bisa mempermudah kelancaran dalam komunikasi. Lambat laun telepon rumah semakin tidak populer karena hadirnya telepon seluler (handphone) yang bisa dibawa kemana saja karena ukurannya yang kecil dan tanpa kabel (nirkabel). Telepon seluler saat ini sudah menjadi bagian dari gaya hidup masyarakat dimana kepemilikannya tidak hanya didasarkan pada fungsi utama telepon seluler sebagai alat komunikasi, tetapi fitur tambahan serta desain produk juga menjadi dasar pertimbangan dalam memutuskan memilih jenis atau merek produk. Untuk berkomunikasi, telepon seluler memerlukan suatu chip (simcard) yang disediakan oleh operator jasa komunikasi.

Semakin populernya telepon seluler, semakin banyak pula operatoroperator di dalam kehidupan masyarakat. Hal ini mengakibatkan semakin tingginya persaingan diantara operator-operator yang ada. Persaingan bisnis yang ketat salah satunya ditunjukan dengan semakin beraneka ragamnya jenis produk dan fitur-fitur yang diberikan atau ditawarkan. Sehingga konsumen semakin diuntungkan karena semakin besar kesempatan konsumen untuk memilih produk yang disukainya dengan nilai-nilai produk yang lebih sesuai dengan harapannya. Hal ini merupakan tantangan bagi produsen, dalam hal ini adalah para operator telepon seluler kartu GSM, karena dengan semakin banyaknya berbagai merek produk yang sejenis beserta fitur-fiturnya yang saling beradu kelebihan memikat konsumen, maka akan semakin besar kemungkinan dari keinginan konsumen 
untuk beralih ke pilihan merek lainnya atau tetap setia pada produk yang disukainya.

Dunia mengenal dua teknologi seluler digital, yaitu GSM dan CDMA. Perlu diketahui, Global System for Mobile Communication disingkat GSM adalah sebuah teknologi komunikasi selular yang bersifat digital. Teknologi GSM banyak diterapkan pada komunikasi bergerak, khususnya telepon genggam. GSM dijadikan standar global untuk komunikasi selular sekaligus sebagai teknologi selular yang paling banyak digunakan orang di seluruh dunia. Kartu GSM terdiri dari dua jenis, yaitu prabayar dan pascabayar. Selain itu juga terdapat kartu CDMA, yang berbeda dengan GSM. Dari populasinya, GSM lebih unggul dibanding CDMA karena ia digunakan lebih awal, tahun 1990-an, dan menerapkan standard terbuka yang dapat dikembangkan siapa saja (http://id.wikipedia.org/wiki/Global_System_for_Mobile_Communications, diakses tanggal 19 Oktober 2009). Karena GSM lebih unggul dalam hal pengguna serta beragamnya jenis operator GSM prabayar yang ditawarkan di Indonesia khususnya lima operator GSM prabayar yaitu : Simpati, XL Mentari, IM3, dan Three (dimana kelima operator tersebut merupakan operator GSM prabayar yang familiar dan populer di kalangan masyarakat umum dan dikalangan mahasiswa), maka menarik perhatian untuk diteliti lebih lanjut mengenai pangsa pasar dan perpindahan penggunaan dari satu merek kartu GSM prabayar ke merek kartu GSM prabayar lainnya yang lebih menarik hati konsumen. Perpindahan pilihan penggunaan kartu GSM tentunya akan mempengaruhi pangsa pasar yang dimiliki operator tersebut. Oleh sebab itu, dalam menghadapi persaingan dalam mendapatkan tempat di hati konsumen, maka operator tersebut perlu mengetahui perpepsi atau penilaian konsumen terhadap peringkat preferensi atribut produk atau layanan tersebut. Operator kartu GSM juga harus mengetahui posisi pesaingnya dan tak kalah pentingnya yaitu perkiraan besarnya pangsa pasar perusahaan saat ini maupun dimasa mendatang. Analisis pasar sangat penting bagi operator dalam meningkatkan keberhasilan bisnisnya. Analisis pasar dilakukan untuk mengetahui seberapa luas pasar produk atau jasa yang bersangkutan, 
bagaimana perkiraan pangsa pasar dengan mempertimbangkan tingkat permintaan, penawaran, posisi perusahaan dalam persaingan, dan bagaimana penilaian konsumen terhadap operator kartu GSM yang ada di Indonesia.

\section{Perumusan Masalah}

Rumusan permasalahan yang akan dibahas adalah :

a.Dari mana mahasiswa Universitas Bunda Mulia memperoleh sumber referensi dalam memilih kelima operator kartu GSM ?

b.Bagaimana penilaian mahasiswa Universitas Bunda Mulia terhadap kelima operator kartu GSM?

c.Bagaimana pangsa pasar kelima operator kartu GSM pada periode berikutnya ?

d.Bagaimana pangsa pasar kelima operator kartu GSM pada kondisi ekuilibrium ?

\section{Tinjauan Pustaka}

\section{Analisis Markov}

Analisis Markov merupakan teknik statistik yang digunakan dalam peramalan perilaku masa depan dari suatu variabel atau sistem state yang dimiliki sekarang atau perilaku yang tidak tergantung pada state atau perilaku setiap saat di masa lalu, dengan kata lain adalah acak. Dalam pemasaran, analisis Markov digunakan dalam pemodelan loyalitas merek di masa depan dari konsumen berdasarkan nilai dari pembelian dan pembelian kembali saat ini. Dalam kualitas kontrol, analisa Markov adalah diterapkan untuk masalah umum yang terjadi dan urutan lainnya tergantung aktivitas, dan dapat menangani sistem degradasi. Penemunya adalah ahli matematika Rusia dan pelopor teori probabilitas yang bernama Andreevich Andrei Markov

(1856-1922) (http://translate.google.co.id/translate_s?q=pengertian+analisis+markov, diakses tanggal 15 Maret 2009).

Rantai Markov menjelaskan dimana gerakan-gerakan dari beberapa variabel di masa yang akan datang bisa diprediksi berdasarkan gerakan-gerakan variabel tersebut di masa lalu(Siswanto 2007),. $K_{t 4}$ dipengaruhi oleh kejadian $K_{t 3}$, 
$\mathrm{K}_{\mathrm{t} 3}$ dipengaruhi oleh kejadian $\mathrm{K}_{\mathrm{t} 2}$, dan demikian seterusnya di mana perubahan ini terjadi karena peranan probabilitas transisional.

\section{Gambar 1}

\section{PROSES MARKOV}

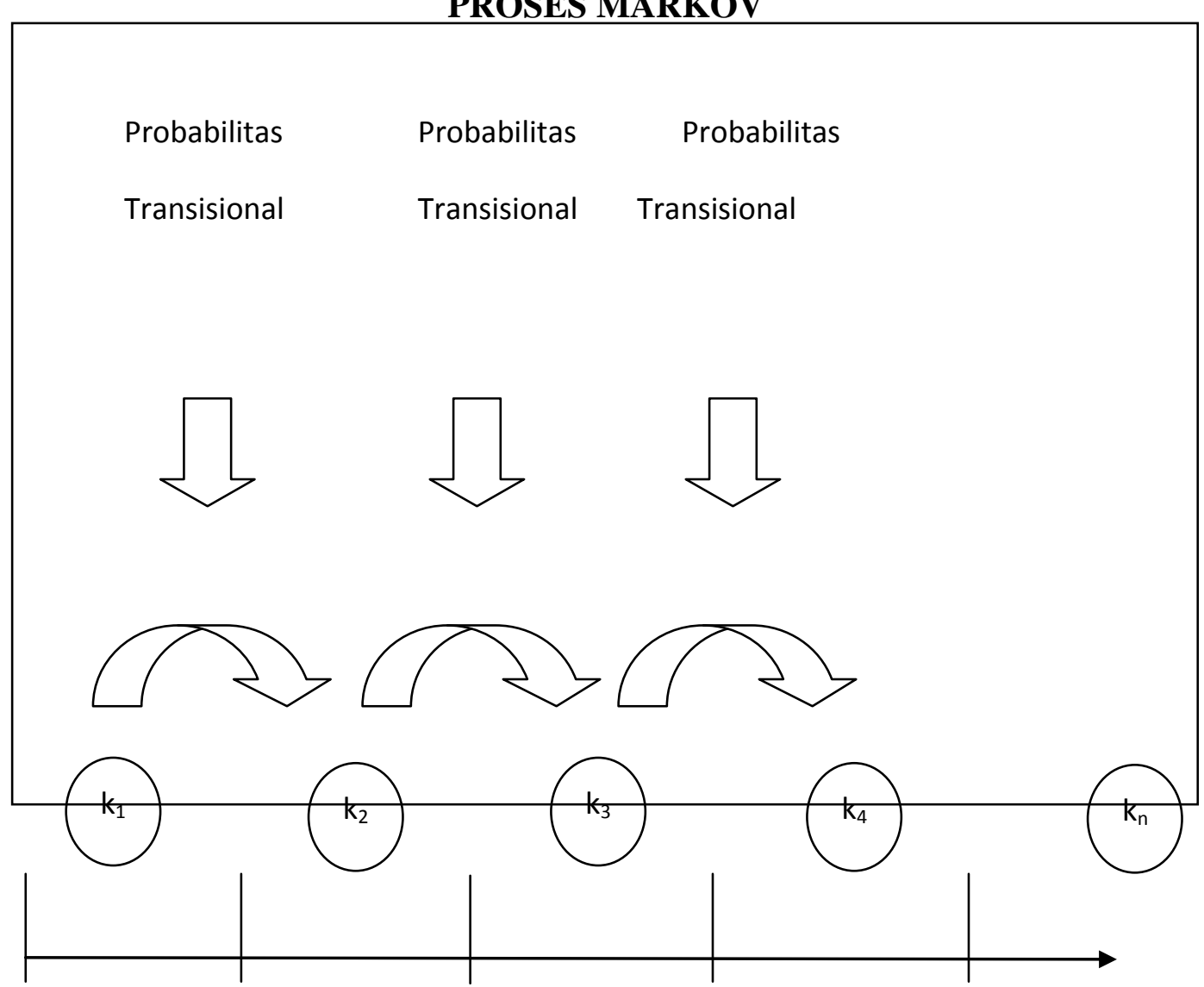

Sumber : (Siswanto 2007)

Rantai Markov menjelaskan gerakan-gerakan beberapa variabel dalam satu periode waktu di masa yang akan datang berdasarkan pada gerakangerakan variabel tersebut di masa kini (Siswanto 2007). Secara matematik, dapat ditulis : 
$K_{t(j)}=P X K_{t(j-1)}$

Dimana :

$$
\begin{aligned}
& \mathrm{K}_{\mathrm{t}(\mathrm{j})}=\text { Peluang Kejadian pada } \mathrm{t}(\mathrm{j}) \\
& \mathrm{P}=\text { Probabilitas Transisional } \\
& \mathrm{t}_{(\mathrm{j})}=\text { Waktu ke } \mathrm{j}
\end{aligned}
$$

Peluang kejadian $\mathrm{Kt}(\mathrm{j})$ dinyatakan ke dalam bentuk vektor sehingga jumlah seluruh selnya akan selalu $100 \%$.

\section{Memprediksi Kondisi di Masa Mendatang}

Salah satu tujuan Markov adalah memprediksi masa depan (Render et al 2007) Berdasarkan contoh kasus sebelumnya, yaitu probabilitas sama dengan pangsa pasar, maka dimungkinkan untuk menghitung pangsa pasar di masa mendatang untuk American Food Store, Food Mart, dan Atlas Food. Jika periode saat ini adalah 0 , menghitung probabilitas state untuk periode berikutnya (periode 1) dapat dilakukan sebagai berikut:

$$
\pi(1)=\pi(0) \mathrm{P}
$$

Jika penghitungan dilakukan pada periode n, maka probabilitas state untuk periode $n+1$ adalah sebagai berikut:

$$
\pi(\mathrm{n}+1)=\pi(\mathrm{n}) \mathrm{P}
$$

Persamaan tersebut dapat digunakan untuk menjawab pertanyaan atas pangsa pasar di masa mendatang untuk ketiga toko bahan makanan. Perhitungannya sebagai berikut: 


$$
\begin{aligned}
& \pi(1)=\pi(0) \mathrm{P} \\
& =(0.4,0.3,0.3) \quad\left[\begin{array}{lll}
0.8 & 0.1 & 0.1 \\
0.1 & 0.7 & 0.2 \\
0.2 & 0.2 & 0.6
\end{array}\right] \\
& =[(0.4)(0.8)+(0.3)(0.1)+(0.3)(0.2),(0.4)(0.1)(0.3)(0.7)+(0.3)(0.2) \\
& (0.4)(0.1)+(0.3)(0.2)+(0.3)(0.6)] \\
& =(0.41,0.31,0.28)
\end{aligned}
$$

\section{Kondisi Ekuilibrium}

(Siswanto 2007), ekuilibrium adalah istilah untuk menandai terjadinya keseimbangan antara dua kekuatan yang saling mencari kondisi yang saling menguntungkan bagi masing-masing, misalnya keseimbangan pasar antara permintaan dan penawaran. Dalam rantai Markov, keseimbangan itu akhirnya membawa $\mathrm{K}_{\mathrm{t}(\mathrm{i})}$ dalam kondisi yang tidak berubah-ubah lagi atau stabil.

Secara matematik, dapat ditulis :

$$
\mathrm{K}_{\mathrm{t}(\mathrm{j})}=\mathrm{P} X \mathrm{~K}_{\mathrm{t}(\mathrm{j}-1)}
$$

Maka, kondisi ekuilibrium akan tercapai jika :

$$
\begin{aligned}
& \mathrm{K}_{\mathrm{t}(\mathrm{eq})}=\mathrm{P} X \mathrm{~K}_{\mathrm{t}(\mathrm{eq})} \\
& \text { Untuk P }=\left[\begin{array}{ll}
0,6 & 0,5 \\
0,4 & 0,5
\end{array}\right] \\
& {\left[\begin{array}{l}
A(e q) \\
B(e q)
\end{array}\right]=\left[\begin{array}{ll}
0,6 & 0,5 \\
0,4 & 0,5
\end{array}\right] \times\left[\begin{array}{l}
A(e q) \\
B(e q)
\end{array}\right]}
\end{aligned}
$$

Diperoleh :

I. $\quad 0,6 \mathrm{~A}_{\mathrm{eq}}+0,5 \mathrm{~B}_{\mathrm{eq}}=\mathrm{A}_{\mathrm{eq}}$

II. $\quad 0,4 \mathrm{~A}_{\mathrm{eq}}+0,5 \mathrm{~B}_{\mathrm{eq}}=\mathrm{B}_{\mathrm{eq}}$

III. $\mathrm{A}_{\mathrm{eq}}+\mathrm{B}_{\mathrm{eq}}=1$

Dari persamaan I,

$$
\begin{aligned}
& 0,6 \mathrm{~A}_{\mathrm{eq}}+0,5 \mathrm{~B}_{\mathrm{eq}}=\mathrm{A}_{\mathrm{eq}} \\
& 0,4 \mathrm{~A}_{\mathrm{eq}}+0,5 \mathrm{~B}_{\mathrm{eq}}=\mathrm{B}_{\mathrm{eq}} \\
& 0,2_{\mathrm{eq}} \frac{\mathrm{A}_{\mathrm{eq}}-\mathrm{B}_{\mathrm{eq}}}{-}
\end{aligned}
$$




$$
\mathrm{B}_{\mathrm{eq}}=0,8 \mathrm{~A}_{\mathrm{eq}} \ldots . . \mathrm{IV}
$$

Jika persamaan IV disubstitusi ke persamaan III maka :

$$
\begin{aligned}
\mathrm{A}_{\mathrm{eq}}+0,8 \mathrm{~A}_{\mathrm{eq}} & =1 \\
1,8 \mathrm{~A}_{\mathrm{eq}} & =1
\end{aligned}
$$

Atau,

$\mathrm{A}_{\mathrm{eq}}=0,555555 \approx 0,555556$

$\mathrm{B}_{\mathrm{eq}}=0,444444$

Jadi,

$$
\left[\begin{array}{l}
0,555556 \\
0,444444
\end{array}\right]=\left[\begin{array}{ll}
0,6 & 0,5 \\
0,4 & 0,5
\end{array}\right] \times\left[\begin{array}{l}
0,55556 \\
0,44444
\end{array}\right]
$$

Menurut Tjia Fie Tjoe dan Haryadi Sarjono (2007, p146), kondisi ekuilibrium merupakan sebuah kondisi yang sangat masuk akal jika di masa mendatang akan tercapai hanya jika tidak ada state yang melakukan tindakan yang dapat mengubah matriks transisi probabilitas.

\section{METODOLOGI PENELITIAN}

\section{Subyek dan Obyek Penelitian}

Subyek penelitian ini adalah mahasiswa Universitas Bunda Mulia jurusan manajemen, semester 8, yang berlokasi di Jalan Lodan Raya no 2 Jakarta Utara. Penulis memutuskan untuk memilih mahasiswa Universitas Bunda Mulia sebagai subyek penelitian dengan pertimbangan pada usia-usia kalangan mahasiswa ini, konsumen yang menggunakan kartu GSM prabayar relatif lebih banyak dikarenakan faktor karakteristiknya yang fleksibel. Hal ini disebabkan oleh beberapa faktor yang mempengaruhi pergantian pemilihan merek kartu GSM prabayar tersebut, seperti perbedaan tarif, layanan, area jangkauan, dan lainnya. Mahasiswa Bunda Mulia Jurusan Manajemen semester 8 dalam penelitian ini mencapai 105 orang, yang terdiri dari beragam pengguna kartu GSM prabayar yang ada. Dan untuk kemudahan dalam pengambilan data dan prediksi pangsa pasar khususnya lima operator GSM prabayar yaitu : Simpati, XL, Mentari, IM3, dan Three (dimana kelima operator tersebut merupakan operator kartu GSM yang familiar dan populer di kalangan masyarakat umumnya dan kalangan mahasiswa 
khususnya terutama mahasiswa Bunda Mulia), serta meminimalkan sumber daya baik waktu, tenaga, dan biaya, maka penulis memutuskan untuk memilih mahasiswa Universitas Bunda Mulia, Jurusan Manajemen semester 8 sebagai subyek penelitian.

Objek penelitian atau variabel penelitian ini adalah mengenai analisis pemilihan kartu GSM prabayar di kalangan mahasiswa yang terdiri dari Simpati, XL, Mentari, IM3, dan Three dengan pendekatan rantai Markov pada mahasiswa Universitas Bunda Mulia jurusan manajemen semester 8. Yang menjadi karakteristik yang diperhatikan dari subyek penelitian ini adalah mengenai sumber referensi mahasiswa dalam pemilihan operator kartu GSM, penilaian mahasiswa terhadap operator kartu GSM, dan pemilihan operator kartu GSM oleh mahasiswa selama dua periode.

\section{Metode Pengumpulan Data}

\section{Jenis Penelitian}

Jenis penelitian yang dilakukan merupakan penelitian deskriptif. Jenis penelitian ini bersifat kualitatif dan kuantitatif.

Penelitian ini mengacu pada masalah mengenai analisa pemilihan kelima operator kartu GSM di kalangan mahasiswa dengan pendekatan rantai Markov oleh mahasiswa Universitas Bunda Mulia jurusan manajemen semester 8. Sedangkan metode penelitian yang digunakan adalah metode survei.

\section{ANALISIS DAN PEMBAHASAN}

\section{Uji Validitas dan Reliabilitas}

Berdasarkan hasil pengolahan data dan analisis data menggunakan program SPPS versi 15.0, maka kuisioner yang disebarkan kepada mahasiswa Bunda Mulia jurusan manajemen semester 8 menunjukkan bahwa :

a. Uji validitas.

Suatu butir pernyataan dikatakan valid jika $\mathrm{r}$ hitung yang merupakan nilai dari Corrected Item-Total Correlation > r tabel (Nugroho 2005),. 
Berdasarkan hasil analisis dengan SPSS versi 15.0 bahwa $\mathrm{r}$ hitung (corrected item-total correlation) setiap item yang diperoleh lebih besar dari $r$ tabel ( $\mathrm{r}$ hitung $>\mathrm{r}$ tabel), dimana $\mathrm{r}$ tabel $=0.192$, $\mathrm{df}=\mathrm{n}-2$ atau $\mathrm{df}=103$. Sehingga dapat disimpulkan bahwa kuisioner tersebut valid.

b. Uji reliabilitas.

Menurut Nugroho (2005, p72), reliabilitas suatu konstruk variabel dikatakan baik jika memiliki nilai Cronbach's Alpha > dari 0,60. Berdasarkan hasil analisis dengan SPSS versi 15.0 bahwa kuisioner tersebut bersifat reliable, karena cronbach's alpha sebesar $0.769>$ dari 0.60 yang ditunjukkan melalui tabel dibawah ini :

Tabel 1

RELIABILITY STATISTICS

\begin{tabular}{|c|c|c|}
\hline Cronbach's Alpha & $\begin{array}{c}\text { Cronbach's Alpha Based on } \\
\text { Standardized Items }\end{array}$ & N of Items \\
\hline
\end{tabular}

\begin{tabular}{|c|c|c|}
\hline 0.769 & 0.770 & 9 \\
\hline
\end{tabular}

Sumber : Hasil Pengolahan Data dengan SPPS

\section{Data Responden Pemakai Kartu GSM}

Responden diambil dari mahasiswa Bunda Mulia jurusan manajemen semester 8 yaitu sebanyak 105 orang. Operator kartu GSM yang diteliti yaitu Simpati, XL, Mentari, IM3, dan Three 
Tabel 2

\section{JUMLAH RESPONDEN, PROBABILITAS, DAN PERSENTASE PADA BERBAGAI OPERATOR KARTU GSM}

\begin{tabular}{|c|c|c|c|c|c|}
\hline No & $\begin{array}{c}\text { Operator Kartu } \\
\text { GSM }\end{array}$ & State & $\begin{array}{c}\text { Jumlah } \\
\text { Responden }\end{array}$ & Probabilitas & $\begin{array}{c}\text { Persentase } \\
(\%)\end{array}$ \\
\hline
\end{tabular}

\begin{tabular}{|c|c|c|c|c|c|}
\hline 1 & Simpati & $\begin{array}{c}\text { State } \\
1\end{array}$ & 10 & 0.10 & $9.52 \%$ \\
\hline 2 & XL & $\begin{array}{c}\text { State } \\
2\end{array}$ & 66 & 0.63 & $62.86 \%$ \\
\hline 3 & Mentari & $\begin{array}{c}\text { State } \\
3\end{array}$ & 3 & 0.03 & $2.86 \%$ \\
\hline 4 & IM3 & $\begin{array}{c}\text { State } \\
4\end{array}$ & 15 & 0.14 & $14.29 \%$ \\
\hline 5 & Three & $\begin{array}{c}\text { State } \\
5\end{array}$ & 11 & 0.10 & $10.48 \%$ \\
\hline \multicolumn{7}{|c|}{ Total } & 105 & 1.00 & $100 \%$ \\
\hline
\end{tabular}

Sumber : Hasil Pengolahan Data

Pada Tabel 2 menunjukkan bahwa terdapat 10 orang yang memilih Simpati dinamakan dengan state 1. Terdapat 66 orang yang memilih XL dinamakan dengan state 2. Terdapat 3 orang yang memilih Mentari dinamakan dengan state 3 . Terdapat 15 orang yang memilih IM3 dinamakan dengan state 4 . Terdapat 11 orang yang memilih Three dinamakan dengan state 5. Dari semua probabilitas yang ada pada tabel 4.2 jika diletakkan dalam vektor probabilitas state maka akan menjadi $: \pi(1)=(0.10,0.63,0.03,0.14,0.10)$ 
Dimana:

$\pi(1)=$ vektor probabilitas state kelima operator kartu GSM untuk periode 1.

$\pi_{1}=0.10=$ probabilitas satu orang yang memilih Simpati (state 1).

$\pi_{2}=0.63=$ probabilitas satu orang yang memilih XL (state 2).

$\pi_{3}=0.03=$ probabilitas satu orang yang memilih Mentari (state 3).

$\pi_{4}=0.14=$ probabilitas satu orang yang memilih IM3 (state 4$)$.

$\pi_{5}=0.10=$ probabilitas satu orang yang memilih Three (state 5).

Berdasarkan kuisioner periode kedua, diperoleh jumlah responden yang memilih operator kartu GSM seperti pada Tabel 4.3 berikut ini :

\section{Tabel 3}

\section{JUMLAH RESPONDEN DAN PERSENTASE KELIMA OPERATOR KARTU GSM PADA PERIODE KEDUA}

\begin{tabular}{|l|c|c|c|}
\hline No & Operator Kartu GSM & Jumlah & \\
Responden & Persentase (\%) \\
\hline
\end{tabular}

\begin{tabular}{|c|c|c|c|}
\hline 1 & Simpati & 7 & $6.67 \%$ \\
\hline 2 & $\mathrm{XL}$ & 67 & $63.81 \%$ \\
\hline 3 & Mentari & 3 & $2.86 \%$ \\
\hline 4 & IM3 & 13 & $12.38 \%$ \\
\hline 5 & Three & 15 & $14.29 \%$ \\
\hline \multicolumn{2}{|r|}{ Total } & 105 & $100 \%$ \\
\hline
\end{tabular}

Sumber : Hasil Pengolahan Data 
Tabel 4

JUMLAH RESPONDEN OPERATOR KARTU GSM SEBELUMNYA DAN SAAT INI

\begin{tabular}{|c|c|c|l|l|c|}
\hline No & $\begin{array}{c}\text { Operator Kartu } \\
\text { GSM }\end{array}$ & $\begin{array}{c}\text { Jumlah } \\
\text { Responden } \\
\text { Sebelumnya }\end{array}$ & Perolehan & Kehilangan & $\begin{array}{c}\text { Jumlah } \\
\text { Responden } \\
\text { Saat Ini }\end{array}$ \\
\hline
\end{tabular}

\begin{tabular}{|c|c|c|c|c|c|}
\hline 1 & Simpati & 10 & 1 & 4 & 7 \\
\hline 2 & $\mathrm{XL}$ & 66 & 8 & 7 & 67 \\
\hline 3 & Mentari & 3 & 1 & 1 & 3 \\
\hline 4 & $\mathrm{IM} 3$ & 15 & 2 & 4 & 13 \\
\hline 5 & Three & 11 & 6 & 2 & 15 \\
\hline \multicolumn{2}{|l|}{ Total } & 105 & 18 & 18 & 105 \\
\hline
\end{tabular}

Sumber : Hasil Pengolahan Data

Tabel 5

BRAND SWITCHING PATERN

\begin{tabular}{|l|l|l|l|l|l|l|l|l|}
\hline \multirow{2}{*}{ No } & \multirow{2}{*}{$\begin{array}{c}\text { Operator } \\
\text { Kartu GSM }\end{array}$} & \multicolumn{5}{|c|}{ Ke } \\
\cline { 4 - 8 } & & Simpati & XL & Mentari & IM3 & Three & $\begin{array}{c}\text { Responden } \\
\text { Sebelumnya }\end{array}$ \\
\hline
\end{tabular}

\begin{tabular}{|c|c|c|c|c|c|c|c|c|}
\hline 1 & \multirow{6}{*}{ : } & Simpati & 6 & 3 & 0 & 0 & 1 & 10 \\
\hline 2 & & $X \mathrm{XL}$ & 1 & 59 & 1 & 1 & 4 & 66 \\
\hline 3 & & Mentari & 0 & 1 & 2 & 0 & 0 & 3 \\
\hline 4 & & IM3 & 0 & 3 & 0 & 11 & 1 & 15 \\
\hline 5 & & Three & 0 & 1 & 0 & 1 & 9 & 11 \\
\hline & & $\begin{array}{l}\text { Responden } \\
\text { saat ini }\end{array}$ & 7 & 67 & 3 & 13 & 15 & 105 \\
\hline
\end{tabular}

Sumber : Hasil Pengolahan Data 
Tabel 6

PROBABILITAS TRANSISI $(P)$

\begin{tabular}{|l|c|c|c|c|c|c|}
\hline \multirow{2}{*}{ No } & \multirow{4}{*}{ Dari } & \multicolumn{5}{|c|}{ Ke } \\
\cline { 3 - 7 } & & Simpati & XL & Mentari & IM3 & Three \\
\hline
\end{tabular}

\begin{tabular}{|c|c|c|c|c|c|c|}
\hline 1 & Simpati & 0.60 & 0.30 & 0.00 & 0.00 & 0.10 \\
\hline 2 & $\mathrm{XL}$ & 0.015 & 0.894 & 0.015 & 0.015 & 0.061 \\
\hline 3 & Mentari & 0.00 & 0.33 & 0.67 & 0.00 & 0.00 \\
\hline 4 & $\mathrm{IM} 3$ & 0.00 & 0.20 & 0.00 & 0.73 & 0.07 \\
\hline 5 & Three & 0.00 & 0.09 & 0.00 & 0.09 & 0.82 \\
\hline & Pangsa Pasar & 0.067 & 0.638 & 0.029 & 0.124 & 0.143 \\
\hline
\end{tabular}

Sumber : Hasil Pengolahan Data

Tabel 7

PERSENTASE PERPINDAHAN PADA BERBAGAI OPERATOR KARTU GSM

\begin{tabular}{|c|c|c|c|c|c|c|c|}
\hline \multirow{2}{*}{$\begin{array}{c}\text { Operator Kartu } \\
\text { GSM }\end{array}$} & \multicolumn{5}{|c|}{ Ke } \\
\cline { 3 - 8 } & & Simpati & XL & Mentari & IM3 & Three & Total \\
\hline
\end{tabular}

\begin{tabular}{|c|c|c|c|c|c|c|c|}
\hline \multirow{4}{*}{5} & Simpati & $60 \%$ & $30 \%$ & $0 \%$ & $0 \%$ & $10 \%$ & $100 \%$ \\
\cline { 2 - 7 } & $\mathrm{XL}$ & $1.5 \%$ & $89.4 \%$ & $1.5 \%$ & $1.5 \%$ & $6.1 \%$ & $100 \%$ \\
\cline { 2 - 7 } & Mentari & $0 \%$ & $33.3 \%$ & $66.7 \%$ & $0 \%$ & $0 \%$ & $100 \%$ \\
\cline { 2 - 7 } & $\mathrm{IM} 3$ & $0 \%$ & $20 \%$ & $0 \%$ & $73.3 \%$ & $6.7 \%$ & $100 \%$ \\
\cline { 2 - 7 } & Three & $0 \%$ & $9 \%$ & $0 \%$ & $9 \%$ & $82 \%$ & $100 \%$ \\
\cline { 2 - 7 } & Responden saat ini & $6.7 \%$ & $63.8 \%$ & $2.9 \%$ & $12.4 \%$ & $14.3 \%$ & $100 \%$ \\
\hline
\end{tabular}

Sumber : Hasil Pengolahan Data 
Berdasarkan data yang telah dijelaskan sebelumnya, maka matriks transisi probabilitasnya akan menjadi seperti yang ada di bawah ini :

$P=\left[\begin{array}{cllll}0.60 & 0.30 & 0.00 & 0.00 & 0.10 \\ 0.015 & 0.894 & 0.015 & 0.015 & 0.061 \\ 0.00 & 0.33 & 0.67 & 0.00 & 0.00 \\ 0.00 & 0.20 & 0.00 & 0.73 & 0.07 \\ 0.00 & 0.09 & 0.00 & 0.09 & 0.82\end{array}\right] \quad \downarrow \quad \mid \begin{gathered}\text { Mempertahankan } \\ \text { dan memperoleh }\end{gathered}$

Arti dari probabilitas di atas adalah sebagai berikut :

\section{Baris 1}

0.60 = probabilitas pangsa pasar Simpati setelah sebelumnya merupakan pemilih Simpati.

0.30 = probabilitas pangsa pasar $\mathrm{XL}$ setelah sebelumnya merupakan pemilih Simpati.

$0.00=$ probabilitas pangsa pasar Mentari setelah sebelumnya merupakan pemilih Simpati.

0.00 = probabilitas pangsa pasar IM3 setelah sebelumnya merupakan pemilih Simpati.

$0.10=$ probabilitas pangsa pasar Three setelah sebelumnya merupakan pemilih Simpati.

\section{Baris 2}

$0.0015=$ probabilitas pangsa pasar Simpati setelah sebelumnya merupakan pemilih XL.

$0.894=$ probabilitas pangsa pasar XL setelah sebelumnya merupakan pemilih XL.

$0.0015=$ probabilitas pangsa pasar Mentari setelah sebelumnya merupakan pemilih XL. 
$0.0015=$ probabilitas pangsa pasar IM3 setelah sebelumnya merupakan pemilih XL.

0.061 = probabilitas pangsa pasar Three sebelumnya merupakan pemilih $\mathrm{XL}$.

\section{Baris 3}

$0.00=$ probabilitas pangsa pasar Simpati setelah sebelumnya merupakan pemilih Mentari.

0.33 = probabilitas pangsa pasar $\mathrm{XL}$ setelah sebelumnya merupakan pemilih Mentari.

$0.67=$ probabilitas pangsa pasar Mentari setelah sebelumnya merupakan pemilih Mentari.

0.00 = probabilitas pangsa pasar IM3 setelah sebelumnya merupakan pemilih Mentari.

$0.00=$ probabilitas pangsa pasar Three sebelumnya merupakan pemilih Mentari.

\section{Baris 4}

$0.00=$ probabilitas pangsa pasar Simpati setelah sebelumnya merupakan pemilih IM3.

$0.20=$ probabilitas pangsa pasar XL setelah sebelumnya merupakan pemilih IM3.

0.00 = probabilitas pangsa pasar Mentari setelah sebelumnya merupakan pemilih IM3.

0.73 = probabilitas pangsa pasar IM3 setelah sebelumnya merupakan pemilih IM3.

0.07 = probabilitas pangsa pasar Three setelah sebelumnya merupakan pemilih IM3.

\section{Baris 5}


$0.00=$ probabilitas pangsa pasar Simpati setelah sebelumnya merupakan pemilih Three.

$0.09=$ probabilitas pangsa pasar $\mathrm{XL}$ setelah sebelumnya merupakan pemilih Three.

0.00 = probabilitas pangsa pasar Mentari setelah sebelumnya merupakan pemilih Three.

0.09 = probabilitas pangsa pasar IM3 setelah sebelumnya merupakan pemilih Three.

0.82 = probabilitas pangsa pasar Three setelah sebelumnya merupakan pemilih Three.

\section{Perhitungan Manual}

\section{Pendugaan Pangsa Pasar pada Periode Berikutnya}

Berdasarkan pada data yang telah dikumpulkan, maka pendugaan peminatan untuk kelima operator kartu GSM untuk periode berikutnya dapat dihitung seperti berikut ini :

$$
\pi(1)=\pi(0) P
$$

Peminatan Matriks transisi probabilitas

Dugaan pangsa pasar

Operator kartu GSM pada

periode berikutnya

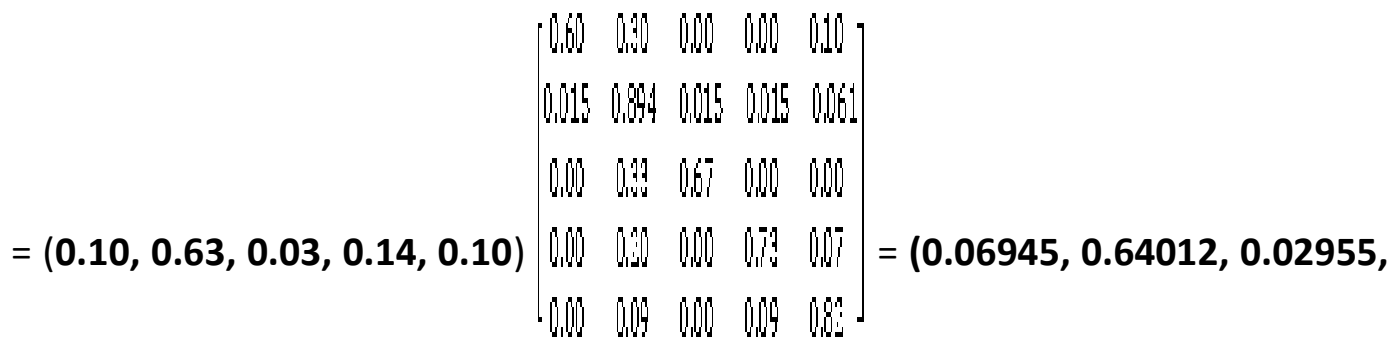

$0.12065,0.14023)$ 
Baris 1 x kolom 1 :

\begin{tabular}{|c|c|c|c|c|c|c|c|}
\hline $\begin{array}{l}\text { Pangsa pasar } \\
\text { Simpati }\end{array}$ & $x$ & $\begin{array}{l}\text { Kecenderungan Simpati } \\
\text { untuk mempertahankan } \\
\text { pelanggannya }\end{array}$ & $=\begin{array}{l}0.1 \\
0\end{array}$ & $x$ & $\begin{array}{l}0.6 \\
0\end{array}$ & $=$ & 0.06 \\
\hline $\begin{array}{l}\text { Pangsa pasar } \\
\mathrm{XL}\end{array}$ & $x$ & $\begin{array}{l}\text { Kecenderungan Simpati } \\
\text { untuk menarik pelanggan } \\
\mathrm{XL}\end{array}$ & $=\begin{array}{l}0.6 \\
3\end{array}$ & $x$ & $\begin{array}{l}0.0 \\
15\end{array}$ & $=$ & $\begin{array}{c}0.0094 \\
5\end{array}$ \\
\hline $\begin{array}{l}\text { Pangsa pasar } \\
\text { Mentari }\end{array}$ & $x$ & $\begin{array}{l}\text { Kecenderungan Simpati } \\
\text { untuk menarik pelangggan } \\
\text { Mentari }\end{array}$ & $=\begin{array}{l}0.0 \\
3\end{array}$ & $x$ & $\begin{array}{l}0.0 \\
0\end{array}$ & $=$ & 0 \\
\hline $\begin{array}{l}\text { Pangsa pasar } \\
\text { IM3 }\end{array}$ & $x$ & $\begin{array}{l}\text { Kecenderungan Simpati } \\
\text { untuk menarik pelanggan } \\
\text { IM3 }\end{array}$ & $=\begin{array}{l}0.1 \\
4\end{array}$ & $x$ & $\begin{array}{l}0.0 \\
0\end{array}$ & $=$ & 0 \\
\hline $\begin{array}{l}\text { Pangsa pasar } \\
\text { Three }\end{array}$ & $x$ & $\begin{array}{l}\text { Kecenderungan Simpati } \\
\text { untuk menarik pelanggan } \\
\text { Three }\end{array}$ & $=\begin{array}{l}0.1 \\
0\end{array}$ & $x$ & $\begin{array}{l}0.0 \\
0\end{array}$ & $=$ & $\underline{0+}$ \\
\hline
\end{tabular}

Baris 1 x kolom 2 :

\begin{tabular}{|c|c|c|c|c|c|c|c|c|}
\hline \multirow{2}{*}{$\begin{array}{l}\text { Pangsa pasar } \\
\text { Simpati }\end{array}$} & \multirow[b]{2}{*}{$X$} & \multirow{2}{*}{$\begin{array}{l}\text { Kecenderungan } \mathrm{XL} \text { untuk } \\
\text { menarik pelanggan Simpati }\end{array}$} & \multirow[b]{2}{*}{$=$} & \multirow{2}{*}{$\begin{array}{l}0.1 \\
0\end{array}$} & \multicolumn{3}{|c|}{0.3} & \multirow[b]{2}{*}{0.03} \\
\hline & & & & & $X$ & 0 & $=$ & \\
\hline $\begin{array}{l}\text { Pangsa pasar } \\
\text { XL }\end{array}$ & $x$ & $\begin{array}{l}\text { Kecenderungan XL untuk } \\
\text { mempertahankan } \\
\text { pelanggannya }\end{array}$ & $=$ & $\begin{array}{l}0.6 \\
3\end{array}$ & $x$ & $\begin{array}{l}0.8 \\
94\end{array}$ & $=$ & $\begin{array}{c}0.5632 \\
2\end{array}$ \\
\hline $\begin{array}{l}\text { Pangsa pasar } \\
\text { Mentari }\end{array}$ & $x$ & $\begin{array}{l}\text { Kecenderungan } \mathrm{XL} \text { untuk } \\
\text { menarik pelangggan } \\
\text { Mentari }\end{array}$ & $=$ & $\begin{array}{l}0.0 \\
3\end{array}$ & $X$ & $\begin{array}{c}0.3 \\
3\end{array}$ & $=$ & 0.0099 \\
\hline $\begin{array}{l}\text { Pangsa pasar } \\
\text { IM3 }\end{array}$ & $x$ & $\begin{array}{l}\text { Kecenderungan XL untuk } \\
\text { menarik pelanggan IM3 }\end{array}$ & $=$ & $\begin{array}{l}0.1 \\
4\end{array}$ & $X$ & $\begin{array}{c}0.2 \\
0\end{array}$ & $=$ & 0.028 \\
\hline $\begin{array}{l}\text { Pangsa pasar } \\
\text { Three }\end{array}$ & $x$ & $\begin{array}{l}\text { Kecenderungan } \mathrm{XL} \text { untuk } \\
\text { menarik pelanggan Three }\end{array}$ & $=$ & $\begin{array}{l}0.1 \\
0\end{array}$ & $x$ & $\begin{array}{c}0.0 \\
9\end{array}$ & $=$ & $\underline{0.009+}$ \\
\hline
\end{tabular}


Baris 1 x kolom 3 :

\begin{tabular}{|c|c|c|c|c|c|c|c|c|}
\hline $\begin{array}{l}\text { Pangsa pasar } \\
\text { Simpati }\end{array}$ & $x$ & $\begin{array}{l}\text { Kecenderungan Mentari } \\
\text { untuk menarik pelanggan } \\
\text { Simpati }\end{array}$ & $=$ & $\begin{array}{l}0.1 \\
0\end{array}$ & $x$ & $\begin{array}{c}0.0 \\
0\end{array}$ & $=$ & 0 \\
\hline $\begin{array}{l}\text { Pangsa pasar } \\
\mathrm{XL}\end{array}$ & $x$ & $\begin{array}{l}\text { Kecenderungan Mentari } \\
\text { untuk menarik pelanggan } \\
\mathrm{XL}\end{array}$ & $=$ & $\begin{array}{l}0.6 \\
3\end{array}$ & $x$ & $\begin{array}{l}0.0 \\
15\end{array}$ & $=$ & $\begin{array}{c}0.0094 \\
5\end{array}$ \\
\hline $\begin{array}{l}\text { Pangsa pasar } \\
\text { Mentari }\end{array}$ & $x$ & $\begin{array}{l}\text { Kecenderungan Mentari } \\
\text { untuk mempertahankan } \\
\text { pelanggannya }\end{array}$ & $=$ & $\begin{array}{l}0.0 \\
3\end{array}$ & $x$ & $\begin{array}{c}0.6 \\
7\end{array}$ & $=$ & 0.0201 \\
\hline $\begin{array}{l}\text { Pangsa pasar } \\
\text { IM3 }\end{array}$ & $x$ & $\begin{array}{l}\text { Kecenderungan Mentari } \\
\text { untuk menarik pelanggan } \\
\text { IM3 }\end{array}$ & $=$ & $\begin{array}{l}0.1 \\
4\end{array}$ & $x$ & $\begin{array}{c}0.0 \\
0\end{array}$ & $=$ & 0 \\
\hline $\begin{array}{l}\text { Pangsa pasar } \\
\text { Three }\end{array}$ & $x$ & $\begin{array}{l}\text { Kecenderungan Mentari } \\
\text { untuk menarik pelanggan } \\
\text { Three }\end{array}$ & $=$ & $\begin{array}{l}0.1 \\
0\end{array}$ & $x$ & $\begin{array}{c}0.0 \\
0\end{array}$ & $=$ & $\underline{0+}$ \\
\hline & & Pangsa pasar Mentari & der & 14 & & atnya & $=$ & $\begin{array}{c}0.0295 \\
5\end{array}$ \\
\hline
\end{tabular}

Baris 1 x kolom 4 :

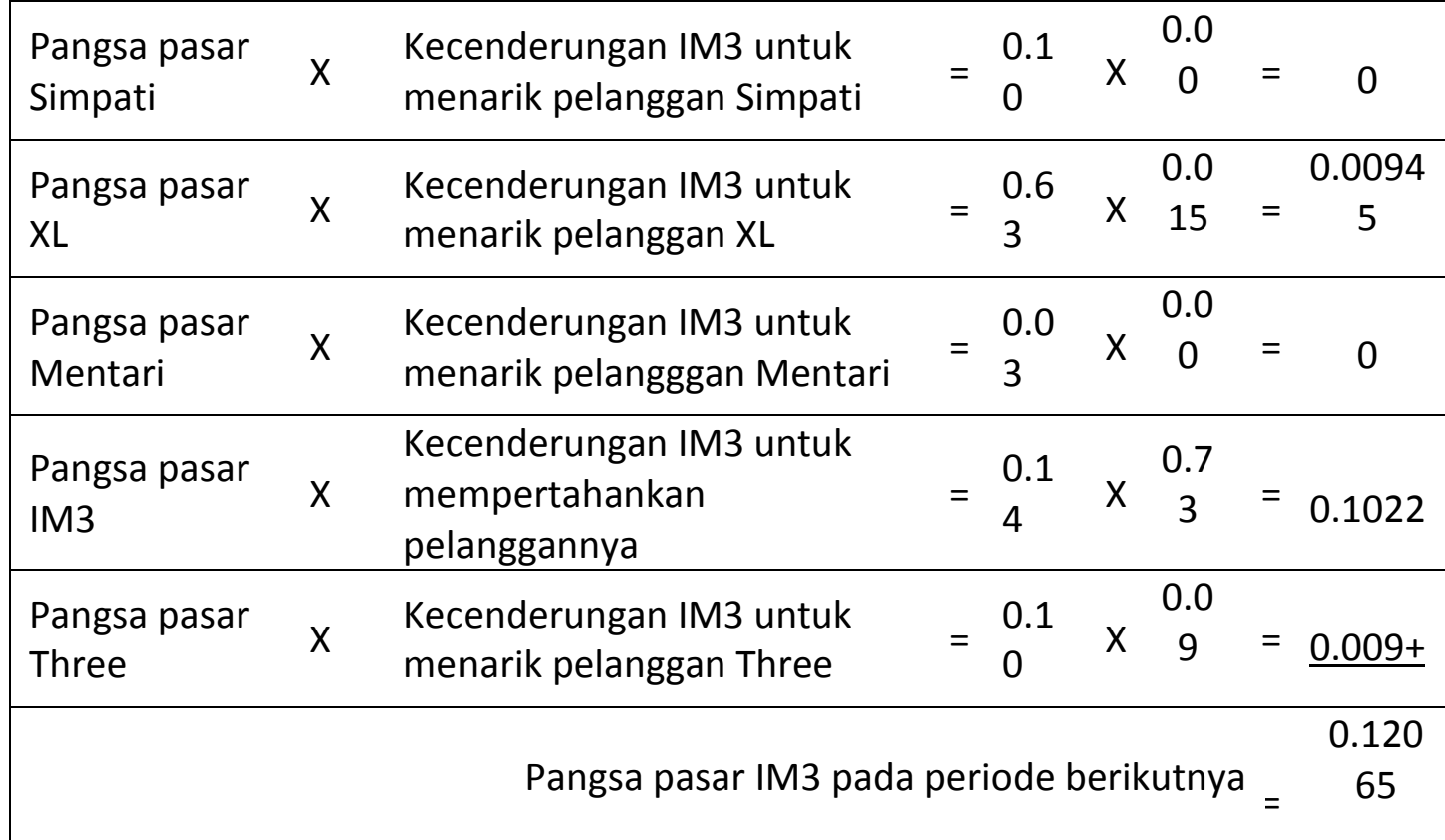


Baris 1 x kolom 5 :

\begin{tabular}{|c|c|c|c|c|c|c|c|c|}
\hline $\begin{array}{l}\text { Pangsa pasar } \\
\text { Simpati }\end{array}$ & $X$ & $\begin{array}{l}\text { Kecenderungan Three } \\
\text { untuk menarik pelanggan } \\
\text { Simpati }\end{array}$ & $=$ & $\begin{array}{l}0.1 \\
0\end{array}$ & $X$ & $\begin{array}{c}0.1 \\
0\end{array}$ & $=$ & 0.01 \\
\hline $\begin{array}{l}\text { Pangsa pasar } \\
\text { XL }\end{array}$ & $x$ & $\begin{array}{l}\text { Kecenderungan Three } \\
\text { untuk menarik pelanggan } \\
\mathrm{XL}\end{array}$ & $=$ & $\begin{array}{l}0.6 \\
3\end{array}$ & $x$ & $\begin{array}{l}0.0 \\
61\end{array}$ & $=$ & $\begin{array}{c}0.0384 \\
3\end{array}$ \\
\hline $\begin{array}{l}\text { Pangsa pasar } \\
\text { Mentari }\end{array}$ & $x$ & $\begin{array}{l}\text { Kecenderungan Three } \\
\text { untuk menarik pelangggan } \\
\text { Mentari }\end{array}$ & $=$ & $\begin{array}{l}0.0 \\
3\end{array}$ & $X$ & $\begin{array}{c}0.0 \\
0\end{array}$ & $=$ & 0 \\
\hline $\begin{array}{l}\text { Pangsa pasar } \\
\text { IM3 }\end{array}$ & $x$ & $\begin{array}{l}\text { Kecenderungan Three } \\
\text { untuk menarik pelanggan } \\
\text { IM3 }\end{array}$ & $=$ & $\begin{array}{l}0.1 \\
4\end{array}$ & $x$ & $\begin{array}{c}0.0 \\
7\end{array}$ & $=$ & 0.0098 \\
\hline $\begin{array}{l}\text { Pangsa pasar } \\
\text { Three }\end{array}$ & $X$ & $\begin{array}{l}\text { Kecenderungan Three } \\
\text { untuk mempertahankan } \\
\text { pelanggannya }\end{array}$ & $=$ & $\begin{array}{l}0.1 \\
0\end{array}$ & $X$ & $\begin{array}{c}0.8 \\
2\end{array}$ & $=$ & $\underline{0.082+}$ \\
\hline & & Pangsa pasar Three pa & & & & itnya & & $\begin{array}{c}0.1402 \\
3\end{array}$ \\
\hline
\end{tabular}

\section{Pendugaan Pangsa Pasar pada Kondisi Ekuilibrium}

Berdasarkan matriks transisi probabilitas dari data operator kartu GSM seperti di bawah ini :

\begin{tabular}{cccccc|c}
\multicolumn{6}{c}{ Mempertahankan dan kehilangan } \\
\cline { 2 - 7 } & $A$ & $B$ & $C$ & $D$ & $E$ & \\
$A$ & 0.60 & 0.30 & 0.00 & 0.00 & 0.10 & Mempertahankan \\
$B$ & 0.015 & 0.894 & 0.015 & 0.015 & 0.061 & dan \\
$C$ & 0.00 & 0.33 & 0.67 & 0.00 & 0.00 & \\
$D$ & 0.00 & 0.20 & 0.00 & 0.73 & 0.07 & \\
$E$ & 0.00 & 0.09 & 0.00 & 0.09 & 0.82 & $\downarrow$
\end{tabular}

Maka matriks di atas dapat diuraikan menjadi lima buah persamaan, dimana Simpati dilambangkan dengan variabel A, XL dilambangkan dengan variabel B, Mentari dilambangkan dengan variabel C, IM3 dilambangkan dengan variabel D, dan Three dilambangkan dengan variabel E. Pangsa pasar Simpati (A) diperoleh dengan menjumlahkan pangsa pasar Simpati (A) + pangsa pasar XL (B) yang pindah ke Simpati (A) + pangsa pasar Mentari (C) yang pindah ke Simpati 
(A) + pangsa pasar IM3 (D) yang pindah ke Simpati (A) + pangsa pasar Three (E) yang pindah ke A (Simpati). Jika dituliskan ke dalam bentuk persamaan maka akan menjadi :

$$
A=0.60 A+0.015 B+0.00 C+0.00 D+0.00 E
$$

Kemudian kita juga dapat menuliskan bentuk persamaan dari pangsa pasar operator kartu GSM B, C, D, dan E. Sehingga kelima pangsa pasar operator kartu GSM tersebut dapat diuraikan menjadi bentuk persamaan seperti di bawah ini :

$$
\begin{aligned}
& A=0.60 A+0.015 B+0.00 C+0.00 D+0.00 E \\
& O=-0.40 A+0.015 B+0.00 C+0.00 D+0.00 E(\text { persamaan } 1) \\
& B=0.30 A+0.894 B+0.33 C+0.20 D+0.09 E \\
& O=0.30 A-0.106 B+0.33 C+0.20 D+0.09 E(\text { persamaan } 2) \\
& C=0.00 A+0.015 B+0.67 C+0.00 D+0.00 E \\
& O=0.00 A+0.015 B-0.33 C+0.00 D+0.00 E \text { (persamaan } 3) \\
& D=0.00 A+0.015 B+0.00 C+0.73 D+0.09 E \\
& D=0.00 A+0.015 B+0.00 C-0.27 D+0.09 E \text { (persamaan } 4) \\
& E=0.10 A+0.061 B+0.00 C+0.07 D+0.82 E \\
& D=0.10 A+0.061 B+0.00 C+0.07 D-0.18 E \text { (persamaan } 5)
\end{aligned}
$$

Karena jumlah dari kelima peminatan sama dengan 1 (satu) maka dapat ditambahkan persamaan sebagai berikut :1 $=\mathrm{A}+\mathrm{B}+\mathrm{C}+\mathrm{D}+\mathrm{E}$

Untuk memecahkan kelima persamaan tersebut maka perlu dilakukan perhitungan matematis dengan cara melakukan eliminasi terhadap persamaanpersamaan tersebut melalui beberapa tahap perhitungan :

\section{Tahap 1}

Pada tahap pertama, lakukan eliminasi terhadap kelima persamaan dengan melakukan eliminasi terhadap tiap dua persamaan yang ada. Persamaan mana yang ingin dipilih tidak mutlak melainkan bebas untuk dipilih. Pada perhitungan 
berikut ini penulis melakukan eliminasi persamaan 1 terhadap persamaan 2, 3, 4, dan 5. Hasil dari tahap pertama yaitu terbentuknya 3 persamaan baru yaitu persamaan 6, 7, dan 8. Berikut merupakan proses eliminasinya :

(Eliminasi persamaan 1 dan 2)

$$
\begin{array}{c|c|c}
0=-0.40 A+0.015 B+0.00 C+ & x & 0=-0.40 A+0.015 B+0.00 C+0.00 D+ \\
0.00 D+0.00 E & 1 & 0.00 E \\
0=\begin{array}{c}
0.30 A-0.106 B+0.33 C+ \\
0.20 D+0.09 E
\end{array} & x & 0=\frac{0.00 A-0.00 B+0.00 C+0.00 D+}{\underline{0.00 E-}} \\
0 & & 0=-0.40 A+0.015 B
\end{array}
$$

(Eliminasi persamaan 1 dan 3)

$$
\begin{aligned}
& 0=-0.40 A+0.015 B+0.00 C+\left|\begin{array}{l|l}
x \\
1
\end{array}\right| 0=-0.40 A+0.015 B+0.00 C+0.00 D \\
& 0.00 \mathrm{D}+0.00 \mathrm{E} \\
& 0=0.00 A+0.015 B-0.33 C+ \\
& 0.00 D+0.00 E \\
& +0.00 \mathrm{E} \\
& 0=\underline{0.00 A+0.00 B-0.00 C+0.00 D+} \\
& \underline{0.00 \mathrm{E}+} \\
& 0=-0.40 A+0.015 B
\end{aligned}
$$

(Eliminasi persamaan 1 dan 4)

$$
\begin{array}{l|l|l}
\begin{array}{l}
0=-0.40 \mathrm{~A}+0.015 \mathrm{~B}+0.00 \mathrm{C}+ \\
0.00 \mathrm{D}+0.00 \mathrm{E}
\end{array} & \mathrm{x} \\
1 & \begin{array}{l}
0=-0.40 \mathrm{~A}+0.015 \mathrm{~B}+0.00 \mathrm{C}+0.00 \mathrm{D} \\
+0.00 \mathrm{E} \\
0=0.00 \mathrm{~A}+0.015 \mathrm{~B}+0.00 \mathrm{C}-0.27 \mathrm{D}+ \\
0.09 \mathrm{E}-
\end{array} \\
\begin{array}{l}
0=0.00 \mathrm{~A}+0.015 \mathrm{~B}+0.00 \mathrm{C}-0.27 \mathrm{D} \\
+0.09 \mathrm{E}
\end{array} & \times \begin{array}{l}
1 \\
0=-0.40 \mathrm{~A}+0.00 \mathrm{~B}+0.27 \mathrm{D}-0.09 \mathrm{E}
\end{array}
\end{array}
$$

(Eliminasi persamaan 1 dan 5)

\begin{tabular}{l|l|l}
$0=-0.40 \mathrm{~A}+0.015 \mathrm{~B}+0.00 \mathrm{C}+$ \\
$0.00 \mathrm{D}+0.00 \mathrm{E}$
\end{tabular}$|\mathrm{x} 1| \begin{aligned} & 0=-0.40 \mathrm{~A}+0.015 \mathrm{~B}+0.00 \mathrm{C}+0.00 \mathrm{D} \\
& +0.00 \mathrm{E}\end{aligned}$ 


$$
\begin{aligned}
& 0=0.10 \mathrm{~A}+0.061 \mathrm{~B}+0.00 \mathrm{C}+ \\
& 0.07 \mathrm{D}-0.18 \mathrm{E}
\end{aligned} \mid \mathrm{x1} \begin{aligned}
& \begin{array}{l}
0=\underline{0.10 \mathrm{~A}+0.061 \mathrm{~B}+0.00 \mathrm{C}+0.07 \mathrm{D}-} \\
0=-0.50 \mathrm{~A}-0.046 \mathrm{~B}-0.07 \mathrm{D}+0.18 \mathrm{E}
\end{array}
\end{aligned}
$$

Tahap 2

Lakukan penyederhanaan pada persamaan 1, 2, 3, 4, dan 5 yang ditunjukkan pada persamaan dibawah ini :

$$
\begin{aligned}
& 0=-0.40 A+0.015 B(\text { persamaan } 1) \\
& 0=0.30 A-0.106 B+0.33 C+0.20 D+0.09 E(\text { persamaan } 2) \\
& 0=0.015 B-0.33 C(\text { persamaan } 3) \\
& 0=0.015 B-0.27 D+0.09 E(\text { persamaan } 4) \\
& 0=0.10 A+0.061 B+0.07 D-0.18 E(\text { persamaan } 5)
\end{aligned}
$$

Dari persamaan 1 di atas dapat diperoleh variabel B melalui perhitungan di bawah ini :

$$
\begin{aligned}
& 0=-0.40 A+0.015 B \\
& 0.40 A=0.015 B \\
& 0.4 A: 0.015=B \\
& B=26.66666667 A
\end{aligned}
$$

Dari persamaan 3 di atas dapat diperoleh variabel $\mathrm{C}$ dengan cara mensubtitusikan variabel $B(B=26.66666667 A)$ ke dalam persamaan 3 tersebut, yang dijelaskan melalui perhitungan berikut :

$$
\begin{aligned}
& 0=0.015 B-0.33 C \\
& 0=0.015(26.66666667 A)-0.33 C \\
& 0=0.4000000001 A-0.33 C \\
& 0.33 C=0.4000000001 A
\end{aligned}
$$




$$
\begin{aligned}
& C=0.4000000001: 0.33 \mathrm{~A} \\
& C=1.212121212 \mathrm{~A} \\
& C=1.21212 \mathrm{~A}
\end{aligned}
$$

\section{Tahap 3}

Setelah melakukan proses eliminasi dan subtitusi pada persamaan 1, 2, 3, 4, dan 5 yang menghasilkan variabel B dan C. Maka untuk memperoleh variabel lainnya, penulis melakukan proses eliminasi terhadap persamaan 8 dan 9 dengan tujuan untuk memperoleh variabel D. Untuk kasus ini, penulis mensubtitusikan variabel B ke dalam persamaan 10 yang diperoleh dari proses eliminasi persamaan 8 dan 9 .

(Eliminasi persamaan 8 dan 9)

$$
\begin{aligned}
& 0=-0.40 A+0.00 B+0.27 D-0.09 E \\
& 0=-0.50 A-0.046 B-0.07 D+ \\
& 0.18 E
\end{aligned}
$$

$$
\begin{array}{l|l}
2 & 0=-0.80 A+0.00 B+0.54 D-0.18 E \\
x 1 \mid & =\underline{-0.50 A-0.046 B-0.07 D+0.18 E+} \\
0 & =-1.3 A-0.046 B+0.47 D
\end{array}
$$

Subtitusikan variabel $B(B=26.66666667 A)$ kedalam persamaan 10 :

$$
\begin{aligned}
& 0=-1.3 A-0.046 B+0.47 D \\
& 0=-1.3 A-0.046(26.66666667 A)+0.47 D \\
& 0=-1.3 A-1.226666667 A+0.47 D \\
& 0=-2.526666667 A+0.47 D \\
& 2.526666667 A=0.47 D \\
& 2.526666667 A: 0.47=D \\
& 5.375886525 A=D
\end{aligned}
$$




\section{Tahap 4}

Berdasarkan perhitungan pada tahap 2 dan 3 maka didapatkan nilai dari variabel $\mathrm{B}=26.66666667 \mathrm{~A}$ dan nilai variabel $\mathrm{D}=5.375886525 \mathrm{~A}$. Langkah selanjutnya adalah memasukkkan nilai variabel B dan D tersebut ke dalam salah satu persamaan 2, 4, atau 5 dengan tujuan untuk mendapatkan nilai variabel E. Pada kasus ini, penulis menggunakan persamaan 5 :

$$
\begin{aligned}
& 0=0.10 A+0.061 B+0.07 D-0.18 E \\
& 0=0.10 A+0.061(26.66666667 A)+0.07(5.375886525 A)-0.18 E \\
& 0=0.10 A+1.626666667 A+0.3763120568 A-0.18 E \\
& 0=2.102978724 A-0.18 E \\
& 0.18 E=2.102978724 A \\
& E=11.68321513 A
\end{aligned}
$$

\section{Tahap 5}

Setelah mendapatkan nilai dari variabel B, C, D, dan E maka langkah selanjutnya adalah menentukan nilai dari variabel A dengan memasukkan nilai variabel yang telah ditemukan ke dalam persamaan berikut ini :

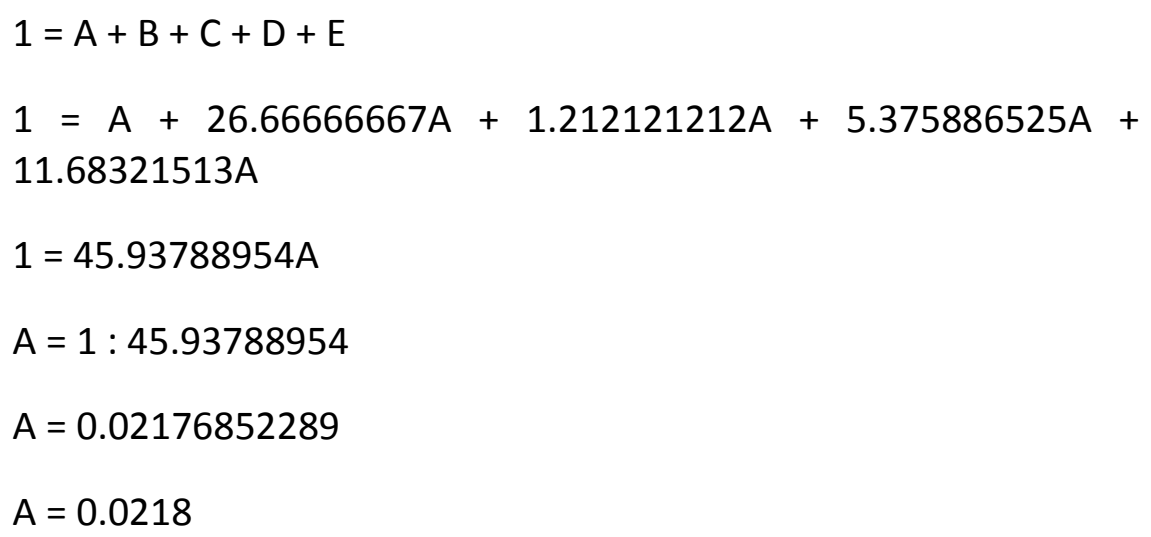

Setelah mendapatkan nilai variabel A, maka masukkan nilai tersebut ke variabel $\mathrm{B}, \mathrm{C}$, dan $\mathrm{E}$ untuk mendapatkan titik ekuilibrium dari kelima variabel (operator kartu GSM) tersebut. 


$$
\begin{aligned}
& B=26.66666667 A \\
& B=26.66666667(0.02176852289) \\
& B=0.5804939438 \\
& B=0.5805 \\
& C=1.212121212 A \\
& C=1.212121212(0.02176852289) \\
& C=0.02638608835 \\
& C=0.0264 \\
& D=5.375886525 A \\
& D=5.375886525(0.02176852289) \\
& D=0.1170251089 \\
& D=0.117 \\
& E=11.68321513 A \\
& E=11.68321513(0.02176852289) \\
& E=0.254326336 \\
& E=0.2543 \\
& B \text {. }
\end{aligned}
$$

Maka titik ekuilibrium pangsa pasar dari Simpati $=0.0218(2.18 \%), \mathrm{XL}=$ $0.5805(58.05 \%)$, Mentari $=0.0264(2.64 \%)$, IM3 $=0.117(11.7 \%)$, Three $=$ $0.2543(25.43 \%)$.

\section{Perhitungan dengan QM for Windows}

Langkah perhitungan dengan software ini adalah sebagai berikut :

1. Input probabilitas state kondisi awal pada kolom Initial, yaitu : $\pi(1)=$ $(0.10,0.63,0.03,0.14,0.10)$. Simpati sebesar 0.10, XL sebesar 0.63, Mentari sebesar 0.03, IM3 sebesar 0.14, dan Three sebesar 0.10. 
2. Input data probabilitas perpindahan dari state $\mathrm{i}$ ke state $\mathrm{j}$, yaitu probabilitas perpindahan dari Simpati ke XL, Mentari, IM3, dan Three, dan seterusnya sesuai dengan matriks transisi probabilitas yang telah dibuat sebelumnya.

$$
P=\left[\begin{array}{ccccc}
0.60 & 0.30 & 0.00 & 0.00 & 0.10 \\
0.015 & 0.894 & 0.015 & 0.015 & 0.061 \\
0.00 & 0.33 & 0.67 & 0.00 & 0.00 \\
0.00 & 0.20 & 0.00 & 0.73 & 0.07 \\
0.00 & 0.09 & 0.00 & 0.09 & 0.82
\end{array}\right]
$$

3. Pada menu jumlah transisi, masukkan jumlah periode yang ingin dihitung. Jika hanya ingin mengetahui probabilitas untuk 1 periode berikutnya maka masukkan jumlah transisi : 1Hasil Analisis Markov pada layar window yang pertama. Berdasarkan menu Markov Analysis Result di bawah ini diperoleh probabilitas pendugaan pangsa pasar berikutnya yaitu $\pi(2)=(0,0695,0.6401,0.0295,0.1207,0.1402)$, dan steady state probability $=(0.0218,0.5805,0.0264,0.117,0.2543)$.

4. Hasil Multiplications memperlihatkan probabilitas state dimulai dari periode awal hingga periode ke-n. Jika ingin mencari probabilitas untuk 2 periode berikutnya dengan jumlah transisi sebanyak 2, maka hasilnya sebagai berikut :

\section{KESIMPULAN}

Setelah melakukan analisis terhadap lima operator kartu GSM (Simpati, XL, Mentari, IM3, Three), maka kesimpulannya adalah sebagai berikut :

1. Sumber referensi pemilihan operator kartu GSM yaitu :

a. $45.71 \%$ responden memperoleh referensi dari teman.

b. $12.38 \%$ responden memperoleh referensi dari keluarga.

c. $29.52 \%$ responden memperoleh referensi dari iklan.

d. $3.81 \%$ responden memperoleh referensi dari event.

e. $8.57 \%$ responden memperoleh referensi dari lainnya. 
Berdasarkan hasil analisis, sumber referensi terbesar bagi responden dalam memilih operator kartu GSM yang diminati adalah berasal dari teman $(45.71 \%)$. Sedangkan sumber referensi terkecil bagi responden dalam memilih operator kartu GSM yang diminati adalah berasal dari event $(3.81 \%)$.

2. Penilaian mahasiswa Bunda Mulia terhadap masing-masing operator kartu GSM meliputi tarif bicara, tarif SMS, sinyal, jangkauan area, harga perdana, harga voucher, layanan, promo, dan fitur adalah sebagai berikut :

\begin{tabular}{|l|l|l|l|l|l|}
\hline Indikator & Simpati & XL & Mentari & IM3 & Three \\
\hline
\end{tabular}

\begin{tabular}{|c|c|c|c|c|c|}
\hline Tarif Bicara & Biasa Saja & Setuju & Setuju & $\begin{array}{c}\text { Biasa } \\
\text { Saja }\end{array}$ & Setuju \\
\hline Tarif SMS & Biasa Saja & Setuju & Setuju & Setuju & $\begin{array}{c}\text { Sangat } \\
\text { Setuju }\end{array}$ \\
\hline Sinyal & $\begin{array}{c}\text { Sangat } \\
\text { Setuju }\end{array}$ & Setuju & Setuju & $\begin{array}{c}\text { Biasa } \\
\text { Saja }\end{array}$ & $\begin{array}{c}\text { Tidak } \\
\text { Setuju }\end{array}$ \\
\hline $\begin{array}{c}\text { Jangkauan } \\
\text { Area }\end{array}$ & $\begin{array}{c}\text { Sangat } \\
\text { Setuju }\end{array}$ & Setuju & Setuju & Setuju & Biasa Saja \\
\hline $\begin{array}{c}\text { Harga } \\
\text { Perdana }\end{array}$ & Biasa Saja & Setuju & Biasa Saja & Setuju & Setuju \\
\hline $\begin{array}{c}\text { Harga } \\
\text { Voucher }\end{array}$ & Setuju & Biasa Saja & Biasa Saja & Setuju & Setuju \\
\hline Layanan & Setuju & Setuju & Setuju & Setuju & Biasa Saja \\
\hline Promo & Biasa Saja & Setuju & $\begin{array}{c}\text { Sangat } \\
\text { Setuju }\end{array}$ & $\begin{array}{c}\text { Biasa } \\
\text { Saja }\end{array}$ & $\begin{array}{c}\text { Sangat } \\
\text { Setuju }\end{array}$ \\
\hline Fitur & Sangat & Sangat & Sangat & Setuju & Sangat \\
& Setuju & Setuju & Setuju & & Setuju \\
\hline
\end{tabular}

Berdasarkan hasil analisis, mahasiswa Bunda Mulia menyatakan sangat setuju bahwa Simpati memiliki sinyal yang kuat, jangkauan area yang luas, dan fitur yang lengkap. Mahasiswa Bunda Mulia menyatakan sangat setuju bahwa XL memberikan fitur yang lengkap. Mahasiswa Bunda Mulia menyatakan sangat setuju bahwa Mentari memberikan promo yang menarik dan fitur yang lengkap. Mahasiswa Bunda Mulia menyatakan setuju bahwa IM3 memberikan tarif SMS yang murah, jangkauan area yang luas, harga perdana yang murah, harga voucher 
yang murah, layanan yang baik, dan fitur yang lengkap. Mahasiswa Bunda Mulia menyatakan sangat setuju bahwa Three memberikan tarif SMS yang murah, promo yang menarik, dan fitur yang lengkap.

Prediksi pangsa pasar pada periode berikutnya adalah :

a. Pangsa pasar Simpati pada periode berikutnya adalah 0.0695 $(6.95 \%)$.

b. Pangsa pasar XL pada periode berikutnya adalah $0.6401(64.01 \%)$.

c. Pangsa pasar Mentari pada periode berikutnya adalah 0.0295 $(2.95 \%)$.

d. Pangsa pasar IM3 pada periode berikutnya adalah 0.1207 (12.07\%).

e. Pangsa pasar Three pada periode berikutnya adalah $0.1402(14.02 \%)$.

Berdasarkan hasil analisis, pangsa pasar terbesar dimiliki XL yaitu sebesar 0.6401 (64.01\%). Sedangkan pangsa pasar terkecil dimiliki Mentari yaitu sebesar 0.0295 (2.95\%).

3. Prediksi pangsa pasar pada kondisi ekuilibrium adalah :

a. Pangsa pasar Simpati pada kondisi ekuilibrium adalah 0.0218 $(2.18 \%)$.

b. Pangsa pasar XL pada kondisi ekuilibrium adalah 0.5805 (58.05\%).

c. Pangsa pasar Mentari pada kondisi ekuilibrium adalah 0.0264 $(2.64 \%)$.

d. Pangsa pasar IM3 pada kondisi ekuilibrium adalah 0.117 (11.7\%).

e. Pangsa pasar Three pada kondisi ekuilibrium adalah 0.2543 $(25.43 \%)$.

Berdasarkan hasil analisis, pangsa pasar terbesar pada kondisi ekuilibrium dimiliki XL yaitu sebesar 0.5805 (58.05\%). Sedangkan pangsa pasar pada kondisi ekuilibrium terkecil dimiliki Simpati yaitu sebesar 0.0218 (2.18\%).

\section{DAFTAR PUSTAKA}

Daft, Richard L. 2007, Manajemen. Edisi 6. Salemba Empat, Jakarta.

Durianto, Darmadi, et al. 2001. Strategi Menaklukan Pasar Melalui Riset Ekuitas dan Perilaku. PT Gramedia Pustaka Utama. Jakarta

Indriantoro, Nur, dan Bambang Supomo. 2002. Metodologi Penelitian Untuk Akuntansi \& Manajemen. Edisi Pertama. BPFE. Yogyakarta.

Nugroho, Bhuono Agung. 2005. Strategi Jitu Memilih Metode Statistik Penelitian dengan SPSS. Yogyakarta. 
Analisis Pemilihan Kartu GSM Prabayar di Kalangan Mahasiswa Dengan Pendekatan Rantai Markov (Studi Kasus Pada Mahasiswa Universitas Bunda Mulia, Jurusan Manajemen Semester 8)

Render, Barry, et al. 2006. Quantitative Analysis For Management. Ninth Edition. Prentice Hall International, Inc. New Jersey.

Sekaran, Uma. 2006. Metodologi Penelitian untuk Bisnis. Buku 1. Salemba Empat. Jakarta.

Umar, Husein. 2003. Riset Pemasaran dan Perilaku Konsumen. Gramedia Pustaka Utama. Jakarta 